\title{
Party innovation, hybridization and the crisis: the case of Podemos
}

\author{
Marco Lisi* \\ NOVA FCSH and IPRI-NOVA, Department of Political Studies, Lisbon, Portugal \\ ${ }^{\star}$ Corresponding author. Email: marcolisi@fcsh.unl.pt
}

(Received 3 December 2017; revised 8 September 2018; accepted 10 September 2018; first published online 12 November 2018)

\begin{abstract}
The literature on populist parties has tended to look at this new phenomenon as distinct from traditional party models. While there are a number of studies focusing on specific dimensions, there have been few attempts to systematically examine the features of these new players through the eyes of distinct party types. This work uses the case of Podemos to highlight what distinguished this new party from mainstream parties. We consider the following dimensions: the genetic model, ideological and programmatic stances, its organization, and the profile of its electoral base. It is shown that Podemos presents hybrid characteristics, combining those of traditional party models with the characteristics transposed from the digital culture. The findings also show that populist parties evolve similarly to mainstream parties and this evolution depends not only on electoral and strategic pressures, but also on the process of institutionalization. The lessons of Podemos will allow us to discuss comparable cases from contemporary democracies, thus strengthening our findings and generating more robust evidence about the (alleged) novelty of populist parties with regard to party models.
\end{abstract}

Keywords: political parties; populism; Podemos; party models; Spain; economic crisis

\section{Introduction}

The recent economic crisis has been a window of opportunity for the emergence and success of (old and) new populist parties, ${ }^{1}$ which have challenged the status quo and the format of party systems throughout Europe. Austerity politics has intensified old grievances and brought new conflicts to the fore. New patterns of mobilization have emerged, while the breakdown of previous loyalties has facilitated the emergence of new actors. In light of this, a number of scholars have argued that the phenomenon of 'protest populism' is of increasing relevance in the context of the euro-crisis (Mair, 2011; Kriesi, 2014; Kriesi and Pappas, 2015). In particular, the advent (and success) of 'new' anti-austerity left parties such as SYRIZA in Greece or Podemos in Spain has triggered increasing interest in the emergence of 'inclusionary' populism in Europe (Mudde and Kasswalter, 2013; see also Calossi, 2016; Damiani, 2016). These cases are often presented as the two most notable examples of 'dramatic organizational change' (Keith and March, 2016, 363).

This article contributes to the debate on new populist parties by looking at Podemos, a Spanish party founded in 2014. Despite the growing interest in this new party, extant research

\footnotetext{
${ }^{1}$ We use the concept of populism as a 'thin ideology' according to the definition elaborated by Mudde (2007, 23): 'a thincentred ideology that considers society to be ultimately separated into two homogeneous and antagonistic groups, the "pure people" versus the "corrupt elite", and which argues that politics should be an expression of the volonté générale (general will) of the people'.
} 
has focused mainly on its ideological orientations (Kioupkiolis, 2016; García and Briziarelli, 2018) its electoral base (Fernandéz-Albertos, 2015; Gomez and Ramiro, 2017) or its membership (Gómez and Ramiro, 2017). However, no comprehensive and systematic studies have been conducted about the party and we do not know the extent to which its features fit - or not - the characteristics of established parties.

Does Podemos represent a new party model? What kind of party is it precisely? What are the specificities of this new party compared to previous party types? By addressing these questions, this study provides a better grasp of the distinctiveness of this phenomenon and its evolution over time. It also offers valuable insights on the capacity of new parties to address the challenges triggered by the Great Recession. In addition, an in-depth analysis of left-wing populist parties allows us to depict the continuities with regard to 'old' left-wing parties, as well as the innovative dimensions of this important subtype of populist parties. These objectives will be achieved by analyzing four main dimensions, namely the genetic model, the programmatic orientations, the organizational component, and the electoral support base. In a nutshell, our argument is that leftwing populist parties politicize new issues, especially in relation to the renewal of democratic regimes, but they do not present particular characteristics in terms of organizational models or mobilization strategies. It will be argued that left-wing populist parties reflect some of the general trends of party transformation in recent decades by interacting with their genetic model, thus giving rise to a hybrid party model. Finally, it will be shown that the removal of intermediation mechanisms implies not only a depoliticization of traditional left-wing issues, but also a weak anchorage in civil society, which ultimately boosts the instability of its electoral base.

By using interviews with party activists, ${ }^{2}$ party documents, and secondary sources, this research offers a fresh interpretation of Podemos' party model and generates new hypotheses about the evolution of left-wing populist parties. In particular, this paper's argument differs sharply with recent research that argues that Podemos presents a 'completely new' party type (Ramiro, 2016, 327; see also Keith and March, 2016), thus innovating traditional organizational models.

The next section defines the key concepts and provides an overview of left-wing populism and its varieties across European countries. We also briefly outline why existing typologies are of limited value in explaining the specificities of left-wing populist parties. Section three examines Podemos' origins, and the subsequent section analyzes its ideological and programmatic stances. Section five focuses on the organizational characteristics and how the party establishes links to civil society. Section six looks at Podemos' electoral support base. The final section discusses our findings and concludes.

\section{Party types, populism, and the radical left}

Previous path-breaking studies on parties have distinguished several party types. Seminal contributions (Neumann, 1956; Kirchheimer, 1966; Duverger, 1981; Gunther and Diamond, 2003) have considered three main party models, namely elite-based parties, mass-based parties, and catch-all (or electoralist) parties. In the 1970s, a new party type emerged, i.e. the movement parties (Kitschelt, 1988). This party family is distinct not only because of the new agenda based on postmaterialist values, but also because it innovates organizationally by adopting characteristics from social movements and grassroots organizations. Kitschelt $(2006,280)$ defines movement parties as 'coalitions of political activists who emanate from social movements and try

\footnotetext{
${ }^{2} \mathrm{We}$ conducted semi-structured interviews with three party activists with different positions within the party in order to have feedback on distinct aspects of internal party life. In particular, we selected one representative of the 'middle-level' elite (a councilor in Madrid municipal Assembly), one MP and one activist elected to the executive committee. The questionnaire covers several dimensions, such as the party origin, factionalism, electoral strategy, mobilization and use of new Information and Communication Technologies (ICT), as well as organizational aspects. The interviews had an average duration of 40 minutes and were granted under the condition of anonymity (see Appendix C).
} 
to apply the organizational and strategic practices of social movements in the arena of party competition'. Their main characteristics are (1) little investment in formal party structures; (2) weak institutionalization of internal decision-making processes and (3) the combination of more 'insider' strategies with extra-institutional mobilization.

In recent decades, the transformation of mass communication and the process of disintermediation have triggered both a weakening of bureaucratic structures and more direct links between party leadership and citizens. Several scholars have devised new party types to address these changes, notably through the electoral professional party (Panebianco, 1988) or the modern cadre party (Koole, 1994) models. The main problem with these categories is that they all rely on the mass party structure (vertical organizational ties). Attempts to overcome this problem have focused on two elements of adaptation. On the one hand, the role of political entrepreneurs and the importance of the personalization of politics have been at the centre of the reformulation of party models. While Hopkin and Paolucci (1999) have proposed the 'business firm' party as a sociopolitical organization stemming from a founding firm, Calise $(2015,304)$ conceptualized a personal party as a 'transformation of the political party where a combination of charismatic and patrimonial resources replaces the collective and legal-rational original party structure'. On the other, Heidar and Saglie (2003) aimed to further specify the modern cadre party by taking into account the role that informal party networks play in elaborating party policies and strategies. In their view, the 'network party' is a combination of 'cadre' and 'mass' elements, which fosters internal communication and debate and valorizes the contribution of party members.

Another influential party type was elaborated by Katz and Mair (1995, 2009) through the cartel party model. This is characterized by 'the interpenetration of party and the state', as well as by a pattern of collusion and elements of plebiscitary democracy (e.g. direct leadership selection). According to these authors, each stage of the evolution of party types generates its own response. From this viewpoint, they argue that cartelization is likely to boost the rise and success of populist anti-party-system parties (Katz and Mair, 2009, 759).

The recent economic crisis has provided a window of opportunity for the emergence of new actors and original forms of political mobilization. Left-wing populist parties may innovate traditional party models by displaying new features in terms of ideology and/or voters' profile on the basis of an 'anti-austerity' appeal (Kriesi, 2014; Calossi, 2016; Damiani, 2016). In addition, a number of authors have argued that the crisis has fostered a divide between responsible and responsive parties, which are based on populist appeals or strategies (Mair, 2011; Kriesi and Pappas, 2015). It is unclear, however, whether these parties may also bring new organizational models to the fore.

To investigate the specificities of (left-wing) populist parties, this study adopts the analytical framework elaborated by Krouwel $(2006,2012)$. Consequently, we focus on three distinct elements. The first is the ideological dimension, which comprises both the basis for party competition and the core values and policies that characterize a political party. The second focuses on the organizational component, which includes the relationship between the party faces, the role of party members and leaders, as well as the power balance between the centre and the periphery. Finally, the third dimension is based on the electoral arena, which differentiates parties according to their electoral appeal and social support.

In order to shed more light on this new phenomenon, we focus on two distinct strands of party literature, namely populism and radical left-wing parties. Populist parties have been studied mainly from the ideological or the electoral perspective. On the one hand, there is growing consensus that the concept of populism implies the opposition and conflict between 'honest' ordinary people and the 'corrupt elite' (Mudde, 2007; Stanley, 2008; Rooduijn and Pauwels, 2011; Pauwels, 2014; Rooduijn, 2014). In particular, "left-populists are "populist" in that the dichotomy between "moral people" and a "corrupt elite" is central to their ideology. They are less concerned about doctrinal purity or class-consciousness than the traditional left (...). Nevertheless, they remain "left" in their emphasis on egalitarianism and the espousal of collective economic and social rights' (March, 2011, 118; see also Chiocchetti, 2017). 
On the other hand, the electoral roots of populist parties are based on anti-political sentiments such as political distrust, discontent, resentment, and also on negative attitudes that citizens develop against representative democracies, the 'establishment', the political elite and the incumbents (e.g. Oesch, 2008; Barr, 2009). But there is also a protest component that may boost the success of these new parties; it is related mainly to government (or system) performance, measured through the satisfaction with political actors and the (perceived) output of democratic regimes. In general, there is broad consensus in the literature that the electoral bases of populist parties are found among more dissatisfied voters, with lower levels of political trust, lower levels of education, ideologically more extreme, with weak social ties and Eurosceptic (Pauwels, 2014; Ramiro and Gómez, 2017).

Unlike ideological and electoral dimensions, there have been few studies on the organizational component of populist parties. Zaslove (2008) is one of the few scholars to associate populist parties to specific organizational traits. From this viewpoint, the populist ideal type includes 'a charismatic and populist leader who claims to possess a direct and unmediated relationship with the people' (Zaslove, 2008, 324), which ultimately leads to a growing centralization and to low levels of party institutionalization. This is in line with March $(2011,118)$, according to whom left-wing populist parties may 'adopt organizational features common to other populist parties across the political spectrum, such as the emphasis on a charismatic leader who has unmediated communication with his people and distaste for formal organization' (see also McDonnell, 2015).

From a theoretical point of view, this study innovates existing literature by identifying one crucial dimension that needs to be considered in order to interpret which model new parties may fit into. This aspect is related to the origin and the genetic model of these new parties. Krouwel $(2006,252)$ differentiates party origin according to two main criteria. The first is whether they emerge from civil society or are closer to the state, and the second is related to the type of agent collective or individual - responsible for the foundation. There is no clear association between party origin and the emergence of left-wing populism, but this typology may elucidate the type of linkages that parties establish with civil society. As shown by radical left parties in Southern Europe, this dimension is extremely important in order to distinguish distinct party types (Backes and Moreau, 2008; Tsakatika and Lisi, 2013; see also Damiani, 2016).

March (2011) studied left-wing populism within the framework of radical left parties, identifying two types of populism in Europe, namely 'populist socialist parties' and 'social populist parties'. As Gómez et al. (2016, 354-355) have argued, March's classification relies mainly on party ideology but it poses several problems, notably with regard to the degree of radicalism and to its empirical validity. This is due principally to the strategic adaptation of the radical left party family and to the dynamic transformation of their ideological and programmatic stances. Zaslove's contribution (2008) also reflects these problems by adopting a definition of left-wing populism based largely on policy orientations. It characterizes left populist parties as a combination of populist discourse with a political platform that is usually associated with socialist or social democratic parties (e.g. social justice, anti-capitalism, anti-globalization, and pacifism). Yet leftist populism differentiates itself from traditional socialist or social democratic parties by playing down class, socialism, and socialist ideology in favour of a political platform that appeals to the 'people'. Contrary to what happens with the populist right, however, the literature on leftwing populist parties has failed to study this new phenomenon in light of existing party models.

If we look at the genetic model, Podemos stemmed from civil society and was associated (mainly) to collective actors. Therefore, the movement party model can be considered as the main benchmark to examine the experience of Podemos (Martín, 2015; see below for more details). Yet it has been noted that the way in which parties combine assembly-based decisionmaking practices and plebiscitary democracy varies greatly (Poguntke et al. 2016). We argue that Podemos is an interesting case because it illustrates (1) the importance of the genetic model and its impact on party evolution and (2) the incapacity of existing typologies to characterize the complex functioning of new parties. In addition, this study advances the literature on (left) 
populist parties by arguing that hybrid traits are likely to generate internal contradictions and tensions between different party faces or arena. In particular, the case of Podemos exemplifies a permanent conflict underlying 'new movement' parties, namely the tension between leaders' attempts to control the party organization and the main strategic decisions on the one hand, and the participatory dynamics on the other.

\section{The roots of a 'new movement' party: Podemos and the crisis of representative democracies}

Much has been written about the origin of Podemos, the importance of the intellectual milieu and television, as well as the fascinating ideas taken from left populism in Latin America that inspired the orientation and style of this new political actor (Müller, 2014; Iglesias, 2015; Martos, 2015; Politikon, 2015; Rivero, 2015; Errejón and Mouffe, 2016; Guedán Vidal, 2016; Tamames, 2016). This section provides the political and social background to better characterize the context that influenced the rise of this new political force.

Podemos stemmed from three distinct traditions (see Prat, 2015; Torreblanca, 2015). First, the extreme left party Izquierda Anticapitalista (IA, Anti-Capitalist Left) was crucial for the new party's organizational support and to provide party cadres with political experience and some political capital. The other important source of inspiration was the 15M-Movement, which abruptly mobilized new groups of citizens and politicized new issues related to the economic crisis $^{3}$. Moreover, a number of social movement activists participated in the launching session of Podemos in Madrid in January 2014. These movements included, for example, Marea Blanca and Marea Verde, two associations for the defence of public health and education, respectively. Last but not least, political scientist professors at Complutense have played a key role as political entrepreneurs, especially in elaborating the discourse and the programmatic orientations, while Iglesias was able to implement a very effective communication strategy.

Podemos' electoral score in its short life has shown a positive trajectory, at least until the 2016 elections (Table 1). In its first elections, the 2014 European elections, Podemos obtained almost 8 per cent $(1,253,837$ of the votes), and elected five MEPs, with remarkable results in the main urban areas. In the 2015 local elections, party leadership decided to form broader alliances with distinct political forces, obtaining positive results in the two main cities (Madrid and Barcelona) where the candidates endorsed by Podemos were elected (see Rodríguez-Teruel et al., 2016). ${ }^{4}$ It was in the 2015 general election that Podemos made its major electoral breakthrough, obtaining a significant result with 20.7 per cent of the votes and 69 seats (19.7 per cent).

Following unsuccessful negotiations among left-wing parties, new general elections were called for 26 June 2016. In this contest, Podemos ran with IU (Izquierda Unida; United Left) in the coalition Unidos Podemos (United we can). In the attempt to secure more centrist voters, campaign coordinator Errejón adopted a moderate strategy, trying to mobilize and persuade undecided voters or the dissatisfied socialist electorate (Rodríguez-Teruel et al., 2016). The main aim was to 'overtake' the PSOE (Partido Socialista Obrero Español, Spanish Socialist Workers' Party) and to rank first in the opposition (left) camp in order to influence post-electoral negotiations. The two parties presented their own symbol in the ballot list, a strategic decision that was important for both symbolic reasons and also the mobilization strategy given their attempt to differentiate the appeal towards distinct groups. However, it had major implications for the composition of party lists, thus creating internal problems within the two parties.

\footnotetext{
${ }^{3}$ For example, the Young without future Platform (Plataforma Juventud Sin Futuro) and Patio Maravillas were two noteworthy phenomena that highlighted the problem of job insecurity and the need to reform the political system. Another key movement was the Plataforma de Afectados por la Hipoteca (PAH), initially founded in 2009 in Barcelona and then spreading throughout the country.

${ }^{4}$ Podemos formed locally differentiated alliances, such as Em Comu Podem (Catalonia), Compromis-Podemos (Valencia) or En Marea (Galicia).
} 
Table 1. Podemos' electoral performance (2014-2016)

\begin{tabular}{lcrrr}
\hline Election & Votes & Votes (\%) & Seats & Seats (\%) \\
\hline 2014-European & $1,253,837$ & 8.0 & 5 & 9.3 \\
2015-Regional & $1,813,044$ & 14.2 & 118 & 14.7 \\
2015-General & $5,212,711$ & 20.7 & 69 & 19.7 \\
2016-General & $5,049,734$ & 21.1 & 71 & 20.3 \\
\hline
\end{tabular}

Source: Ministerio del Interior.

The election results were very disappointing for the party leadership. The new coalition was not able to overtake the PSOE - contrary to what most opinion polls had suggested before the elections -, nor did it increase the number of total votes. Although the proportion of votes was higher than in previous elections - due to higher abstention - the two leftist parties failed to mobilize new voters or to expand their consent within less traditional strongholds (more rural areas and small cities) (Simón, 2016).

\section{Against austerity, towards democratic renewal: left-wing populism, Podemos style}

This section examines Podemos' programmatic orientations in order to assess the populist character of the discourse elaborated by this new party. It will be argued that the programme is a combination of traditional leftist - especially left-libertarian - policies with the politicization of new issues related to the renewal of representative democracies. This means that the populist nature of Podemos' programme relies mainly on its antiestablishment stances, which have an 'inclusive' feel associated to socio-economic policies based on state intervention in the economy, a strong welfare component and the defence of social and economic democracy.

First, Podemos' ideology was articulated in an attempt to construct a new cleavage through a vertical division between the people and the 'caste'. On the one hand, we have 'normal' people, workers, or the 'social majority'. On the other, there is the political elite (composed of the main moderate parties: PSOE, Partido Popular, Popular Party [PP], and UPyD [Unión, Progreso y Democracia, Union, Progress and Democracy]), which is unresponsive to citizens' preferences and insulated from popular needs and concerns. Thus, we find Podemos has the antagonistic divide that is typical of populist actors and that should be replaced with popular unity with the aim of achieving the common good (Kioupkiolis, 2016; Gómez-Reino and Plaza-Colodro, 2018).

On traditional socioeconomic issues, Podemos displays anti-neoliberal stances based on expanding welfare provision financed through increased taxation of high capitals, and also stronger state intervention in the economy and the implementation of redistributive policies (Podemos, 2015b). For instance, the programme advocated increasing the minimum wage and public pensions, as well as the need to set a maximum for incomes. It also proposed reducing working hours (35-hour working week) and lowering the retirement age (60). On the other hand, Podemos supported growing public control over strategic economic and social sectors, such as health, education, transportation, and communications (Ramiro, 2016). Finally, the economic proposals included in the 2015 election manifesto also defended anti-austerity measures such as the restructuring of the public debt.

Regarding left-libertarian issues, Podemos strongly advocated a national plan for energetic transition with the aim of fostering sustainable development and increased use of renewable energy. Particular emphasis is placed on the public management of natural resources - for example, water, forests, coasts - and communication (Podemos, 2016). Gender egalitarianism is also defended by implementing 'parity laws' in the public and private sectors. Finally, the programme supports the end of the Concordat with the Holy See and freedom of conscience.

While Podemos' programme has similarities with other radical left parties with regards the main socioeconomic and cultural issues, the discourse on the deepening of democracy and the reform of the representative political system were framed according to a populist rhetoric. The Podemos programme defends that the roots of the current crisis lie not only in economic 
inequalities and the imbalances of capitalism, but also in the oligarchic character of the Spanish society and the fact that many political decisions are taken against the will of the majority. In other words, the crisis has two faces, one economic and the other political. This situation resembles the notion of 'post-democracy' as defined by Crouch (2004), that is, a condition in which voting has no significant consequences because political elites do not respond to the public but only to big business.

The programme for the 2015 elections includes a strong emphasis on instruments of direct democracy, namely through popular initiatives, deliberation (participatory budgeting and use of public spaces), as well as popular veto based on referendums to reject laws. One of the crucial proposals was based on the permanent recallability of MPs with a view to strengthening accountability and enforcing more responsiveness (Podemos, 2015a). Moreover, all authorities elected to public office should be chosen by primaries, while the General Council of the judiciary power should also be directly elected by citizens. Other proposals sought to reform public administration and fight corruption through the elimination of privileges for politicians, more severe measures to tackle corruption, a depoliticization of the Constitutional court, a reduction in the number of senior state positions and a stricter regime of incompatibilities for public offices. The overall objective was to open up state institutions and to reverse the electorate's current scepticism about politicians.

An important component of the populist rhetoric was the criticism of the European Union. This critical stance is not only in relation to the social model, but also to the political functioning of the main institutions. However, the program for the 2016 elections was more moderate than previous manifestos, with only 'minimal' reforms that do not substantially undermine the integration process. The main point is related to the elimination of the Fiscal Stability Treaty, as well as the need to implement a European fiscal policy with better coordination among countries (Podemos, 2016). There are also some general references to the democratization of European institutions and the call for a conference on debt restructuring. Podemos distinguishes itself from traditional radical left parties above all through the link between populism and Euroscepticism in that the party leadership has elaborated a Manichaean discourse around the opposition between the 'common people' ('la gente' or la 'mayoría social') and the 'caste', i.e. the elites and the privileged, which also include European leaders (Gómez-Reino and Plaza-Colodro, 2018).

Podemos has gone through a process of moderation, especially with regard to European and foreign policy matters. In the first election manifesto, the idea was to call popular referendums on the acceptance of European treaties, North Atlantic Treaty Organization membership and the participation in international missions. In 2015, the party did not openly oppose the country's international responsibilities, although it expressed some criticism (Podemos, 2015b). The shift in programmatic orientations is also clear if we look at some important economic policy stances, such as debt restructuring and the nationalization of strategic enterprises, which were removed from the 2016 manifesto (see also Prat, 2015; Rodríguez-Teruel et al., 2016).

Overall, Podemos' programmatic orientations combine traditional social-democratic and leftlibertarian policies with the politicization of new issues; their aim was to reform the overall political system through the empowerment of citizens and the introduction of more tight controls on politicians. Its ideological proximity to the radical left is confirmed by its membership in the transnational group in the European Parliament of the European United Left/Nordic Green Left (GUE/NGL). However, it should be noted that radical ideological terms were cleared from the main leftist proposals; for example, the word 'class' was never used in the programme. Therefore, some ideological dimensions and especially those related to labour issues were also depoliticized, thus making it even more difficult to establish links with specific social groups (Interview 1). As Ramiro and Gómez (2017) have noted, the peculiar combination between traditional policy stances and an innovative discourse adopted by its leaders have made Podemos a special case in the radical left party family and other party models (see Gunther and Diamond, 
2003). ${ }^{5}$ In the next section, we assess its organizational features within the framework of different party models.

\section{Podemos' double face: between deliberation and centralization}

The organizational roots of Podemos were inspired by the mobilization of the Indignados Movement that spread through numerous and spontaneous protests across Spain; this was a significant symbolic resource for the new party (Torreblanca, 2015). In addition to being mass mobilization usually involving depoliticized or more alienated groups, its legitimacy and the empowerment of new groups of citizens also made this experience important.

This grassroots mobilization, which is a typical feature of the 'movement party' model, made it more difficult for the new party to build an organizational structure with a reasonable territorial penetration. Moreover, time constraints made it almost impossible to create a basic party structure from scratch (Interview 2). As a result, when the opportunity arose to join forces with existing party organizations, it seemed the best solution. With the 'marriage of convenience' between Podemos and IA, the small far-left party was able to benefit from Iglesias' popularity, ${ }^{6}$ while the new political force would gain the organizational roots of IA.

During the Constituent Assembly, there was a heated debate on the organizational model the party should adopt. Echenique and Iglesias presented the two main documents. The first model was based on the political and financial independence of the circles - the main local party units -, thus defending a high degree of decentralization and autonomy. For example, circles would be given the power to choose their own candidates and to decide their own alliance strategy. In contrast, the organizational model proposed by Iglesias centred on the Citizen Council (Concejo Ciudadano), the highest party body between assemblies, together with a party leader with great powers in order to ensure unity of action and coherent political discourse. ${ }^{7}$ Moreover, the collegial leadership defended by IA leaders was in opposition to the centralization of decisionmaking processes advocated by Iglesias. In June 2014 party affiliates chose Iglesias' model, thus allowing him to establish de facto control over internal party functioning. The 62 members elected to the Citizen Council from the Constituent Assembly all belonged to Iglesias' list, and the new leader was elected with an overwhelming majority vote ( 88.6 per cent). This is one of the main plebiscitary characteristics of the new party, as the collective party body has significant powers, most notably the responsibility to decide party strategy (see art. 13 of party statutes, Podemos 2015a).

The conflict between the two main components within Podemos - participatory and plebiscitary - is still one of the key characteristics of intraparty functioning (Borge and Santamarina, 2015; Torreblanca, 2015). However, new conflicts have also emerged, especially within the parliamentary group and between the centre and party branches in the Spanish autonomies (Rodríguez-Teruel et al., 2016). Moreover, some strategic divisions have emerged between Iglesias and his right arm, Errejón, especially on the politics of alliances and the mobilization strategy (Interviews 2 and 3). Besides direct links between the leadership and the party on the ground, co-optation has been one of the strategies used to keep party unity and to empower Iglesias' leadership. ${ }^{8}$

Podemos attempted to recreate and implement some of the central features of social movements by using new technologies. Never before had a Spanish party used social media and new digital communication tools with such success, as the number of Facebook and Twitter followers clearly demonstrates (Torreblanca, 2015). ${ }^{9}$ Direct digital democracy was enhanced through

\footnotetext{
${ }^{5}$ However, some new actors - such as the France Insoumise - have attempted to adopt similar features.

${ }^{6}$ It should be noted that IA Left obtained less than 25,000 votes in the 2009 European elections ( 0.1 per cent of total votes).

${ }^{7}$ According to our interviews, Iglesias' main aim was to build an efficient electoral machine with the aim of overtaking the Socialist party.

${ }^{8}$ See the appointment of Echenique as the secretary for organization (El País, 16 March 2016).
} 
several types of applications. For example, 'Agora voting' allows sympathizers to vote simultaneously on different issues using their computer or mobile phone; 'Plaza Podemos' sought to connect citizens and aggregate the ever more fragmented demands from civil society; and 'appgree' enables party members to choose specific issues for discussion, formulate questions, vote and express their preferences for decisions (Borge and Santamarina, 2015; Gerbaudo, 2015; Casero-Ripollés et al., 2016).

These tools were of strategic importance when formulating the manifesto for the 2015 general elections because they ensured a participatory process that facilitated the transmission of citizens' demands to the party leadership, without intervention from experts. This innovative mode of policy formulation contrasts sharply with the highly centralized and closed patterns of functioning that had been characteristic of Spanish politics (Vèrge, 2007). Podemos' innovation relies on a new model of participation that is more inclusive and bottom-up; it combines a deliberative moment, made possible by new technologies, with an effort to mobilize the party on the ground. For example, Podemos created 'Ágora exterior' in an attempt to coordinate and represent the preferences of Spanish people (mostly young) that live abroad, using online meetings (every three months) and other digital tools (Interview 3).

One of the peculiarities of Podemos' organization is the Citizen Assembly (Asamblea Ciudadana), which includes party members without intermediators (delegates). This party body is formally responsible for key issues, such as leadership and candidate selection, party strategy and statutes. It convenes at least every three years and it uses online voting to take its decisions. However, until now it has always endorsed party leader's orientations (see Rodríguez-Teruel et al., 2016). The Assembly selects members of the Citizen's Council (Consejo Ciudadano), including the national party leader and the 17 regional party leaders, through open lists. This party body has played a largely advisory role and is the institutional arena where party factions deliberate and negotiate (Interview 1). On the other hand, the Secretaría General (general secretariat), which is elected by the Assembly through closed lists, has been the main executive committee and takes the day-to-day decisions. ${ }^{10}$ The party leader heads the list for the general secretariat, but it is not an autonomous party body. It is also worth noting that all positions in Podemos can be subjected to revocatory processes.

The organizational model adopted by Podemos was characterized by its decentralization and a sort of 'franchising' model (Carty, 2004), ${ }^{11}$ which granted the circles a high level of autonomy (Podemos, 2014). These circles - inspired by the 'Bolivarian circles' implemented in Venezuela by Chávez (Tímermans, 2014) - were conceived as 'voluntary grouping, open and autonomous', so as to foster political change and popular democracy. Party statutes establish two types of circle: the first is territorial, and the second is functional, organized through specific themes or interests. The circles grew rapidly (to roughly 200) until the European elections in May 2014 and continued this trend until the 2015 general elections. ${ }^{12}$ In Podemos' second Assembly (2017), new sectoral circles have been created for women ('Feminist Circles'), LGTB and expats. Moreover, a new party agency (called 'Consejo rural $y$ de la mar') was also formed with the aim of fostering penetration in rural areas (Annex III, 2017 statutes).

\footnotetext{
${ }^{9}$ The number of Podemos' followers in social networks is significantly higher than the figures reported for traditional mainstream Spanish parties. Recent data show an outstanding increase in Twitter followers, from 585,000 to 1,333,225 between May 2015 and May 2018, while Facebook followers have jumped from 955,248 to 1,189,098 during the same period.

${ }^{10}$ The Citizen's council elects some members (between 10 and 20) to form, with the general secretariat, the 'Coordination council', whose goals are to coordinate internal activities and execute 'political tasks'. Regional and local structures replicate the national organizational configuration (see Appendix D for the organizational chart).

${ }^{11}$ Behind the franchising model lies the concept of stratarchy, according to which there is a mutual autonomy between the local and the national party, a functional differentiation among different faces or units of political parties.

${ }^{12}$ According to Torreblanca (2015), more than 1,000 circles were created in about one year. There are no reliable data on the numbers of active and inactive circles in 2018, but party headquarters point to the existence of approximately 1,500 circles (less than 100 abroad).
} 
The functioning of the party on the ground through the 'circles' has revealed some limitations in Podemos' capacity of representation and mobilization. First, a significant proportion of these structures are inactive ('zombie circles'), with no real participation. As a consequence, party leadership started an updating process in 2016 in order to revitalize the circles. Second, most circles do not debate key political issues but focus mostly on local problems or marginal policies (Interview 3). Finally, these structures are not connected to decision-making processes and there are often difficulties in finding a compromise between the distinct opinions and preferences presented in these forums (Interview 2).

Alongside this decentralization and deliberation, a trend towards centralization has emerged with regard to decision making on strategy and key matters (Prat, 2015; Rodríguez-Teruel et al., 2016, 9-12). Problems of this kind arose during the primaries before the 2015 general elections. Party leadership decided that the list should be made at the national level, rejecting the proposal for the regional or provincial selection of candidates. ${ }^{13}$ In practice, party leadership controls the most important decisions, while both the party in public office and the party in central office are subordinated to the executive agency. As one of the interviewees noted, 'everybody is aware that the position of Iglesias is key within the party, not only because it ensures coordination among elites, but also because he is an important asset for communicating the party message to the electorate' (Interview 1). This centralization can also be seen in the most important decisions taken in the second Assembly held in 2017, where the overwhelming majority of voters approved the choices and documents prepared by the party leadership. ${ }^{14}$

As for party membership, party statutes establish low barriers for entering into the party organization. In fact, members have to enrol but do not need to pay a fee (Podemos, 2015). They are entitled to participate in the Citizen Assembly, which grants them huge powers in the internal party life, for example, in the politics of alliance, candidate selection, programme, pre or postelectoral agreements and election of internal party bodies (art. 11). Besides the limited membership requirements, there are no differences between members and leaders and any member may be selected for a party office, thus rejecting the principle of professionalization (Podemos, 2014). Indeed, there is no probation period and all adherents enjoy the same rights with no constraints; belonging to another party is not forbidden (Gómez and Ramiro, 2017).

The creative use of new communication technologies and the functioning of the circles made it more difficult to distinguish outsiders and insiders, while participation is reconfigured as an 'open source programme' (Kioupkiolis, 2016, 105), with variable degrees of involvement. From this perspective, Podemos can also be considered as a prototype of the 'network' party (Heidar and Saglie, 2003), which connects in different ways and through distinct modalities: new ICT, traditional media and local party units. Despite the loosening organizational structure, Podemos differs from this party model above all because it does not present traditional party branches. In addition, this does not mean that horizontal links have prevailed within the party or that intraparty functioning is based on informal mechanisms. While less institutionalized dynamics characterize the life of Podemos' circles, decision-making processes at the central level are more structured and standardized (Interview 3). In practice, while some of the original characteristics associated to the 'movement party' type - have been lost due to electoral pressures, vertical links and centralization have prevailed, thus enhancing the 'old-style' representative politics (Kioupkiolis, 2016, 106). In other words, Podemos seems to suffer from the same pressures that traditional parties have experienced with regards personalization, individualization, and professionalization.

\footnotetext{
${ }^{13} \mathrm{El} \mathrm{Mundo,} 27$ July 2015. It is also worth noting that the first party statutes established only a collegial leadership and did not recognize the formal role of party leader, which emerged later with the position of 'general secretary'.

${ }^{14}$ However, since the explosion of the Catalonia problem in 2017, the image of Iglesias has gradually declined among the electorate, leading to a loss of popular support.
} 
Yet the organizational structure of Podemos is far from assuming traits similar to those of conventional parties in contemporary democracies. Contrary to cadre or catch-all parties, this new party still values members' recruitment and participation, not only as a source of legitimacy but also in terms of electoral benefits. ${ }^{15}$ Furthermore, political decision-making tends to be more participatory and less predictable than in other parties due to the substantial internal diversity of political opinions and factionalism. On the other hand, the use of new ICT has paved the way to new forms of mobilization and decision-making processes, strengthening participatory linkages and grassroots democracy. There is also consensus on some basic principles such as the turnover of public officers, gender quotas and the imposition of limits to party and institutional mandates. Finally, Podemos lacks a charismatic leadership as a source of legitimacy that defines the essence of personal parties (see above). In short, Podemos' 'populist' organizational features are still very close to the characteristics of movement parties (Kitschelt, 2006).

Furthermore, similar to other left-wing parties (see Keith and March, 2016), it presents some remarkable ambivalences. The tension between horizontality vs. verticality, internal pluralism vs. cohesion and efficacy, as well as between centralization and decentralization is a key element of Podemos organizational model (Kioupkiolis, 2016). This ambivalence emerged in the second party congress (Vistalegre II) held in February 2017, when the organizational documents presented by Iglesias and his right arm Errejón were discussed. While there was consensus on the need to boost decentralization and to enhance internal participation (especially through the empowerment of the circles and a better articulation with party representatives in local government), the two main proposals differed in important dimensions. ${ }^{16}$ First, Iglesias supported the adoption of a majoritarian principle to elect the Coordination Council, while Errejón defended a two-thirds majority. Second, while Iglesias' proposal advocated a direct election of the Citizen Council by all party members, his main opponent backed the representation of territorial and local party structures. Finally, and most importantly, Errejón aimed to give decision-making processes a more collegial nature, to foster power-sharing mechanisms and to increase the deliberative nature of internal debates - as opposed to plebiscitarian mechanisms and the discretionary use of direct democracy tools in the hands of the party leader. ${ }^{17}$

These distinct models were associated to the intense strategic debate regarding the politics of alliance and the interaction between the institutional arena and social mobilization (García de Blas, 2017). According to Errejón, Podemos' voters are more moderate and more prone to cooperate with other political forces - for example, the PSOE -, whereas the leadership aims to radicalize the patterns of competition and to attract dissatisfied voters, eroding the basis of support of mainstream parties. Iglesias was the clear winner in the election for the secretarygeneral, although the split between the three main factions was evident in the election of the main party bodies (Table 2). Besides Iglesias' inner core, Errejón has emerged as the main internal opponent and tried to consolidate his internal support when the crisis erupted after the scandal of Madrid's regional president in 2018. ${ }^{18}$ His candidacy to the Community of Madrid has also been supported by Carolina Bescansa, one of Podemos' founding members; despite no 'organic' support within the party organization, Errejón's behaviour has been interpreted as a strategic move to compete for the national leadership in the next general elections. ${ }^{19}$ On the other hand, Miguel Urbán, MEP and member of IA, has emerged as the leader of the third

\footnotetext{
${ }^{15}$ See, for instance, the open letter published by Errejón to members and sympathizers for the mobilization in the 2016 campaign.

${ }^{16}$ See the documents 'Mandar Obedeciendo' and 'Recuperar la ilusión', presented by Iglesias and Errejón, respectively. The anti-capitalist sector (Podemos en Movimiento) also proposed a distinct organizational document.

${ }^{17}$ 'Las corrientes de Podemos. Diferencias y similitudes en los modelos de partido', El Independiente, 23 January 2017.

${ }^{18}$ The head of Madrid's regional government, Cristina Cifuentes (Popular Party), resigned in April 2018 due to several wrongdoings.

${ }^{19}$ See https://politica.elpais.com/politica/2018/04/19/actualidad/1524125992_790926.html.
} 
Table 2. Documents voted for at the 2017 party meeting (Vistalegre II), results

\begin{tabular}{|c|c|c|c|c|c|c|}
\hline & \multicolumn{2}{|c|}{ Political document } & \multicolumn{2}{|c|}{ Organizational document } & \multicolumn{2}{|c|}{ Citizen Council } \\
\hline & Votes & $\%$ & Votes & $\%$ & Points ${ }^{a}$ & $\%$ \\
\hline Iglesias & 85,946 & 56.04 & 83,385 & 54.42 & $138 \mathrm{M}$ & 50.78 \\
\hline Errejón & 51,701 & 33.71 & 53,415 & 34.86 & $92 \mathrm{M}$ & 33.68 \\
\hline Podemos en Movimiento & 13,689 & 8.93 & 15,333 & 10.01 & $36 \mathrm{M}$ & 13.11 \\
\hline Podemos en Equipo & 700 & 0.46 & 1,092 & 0.71 & - & - \\
\hline Juan Moreno Yague & 1,324 & 0.86 & - & - & - & - \\
\hline Blank/invalid votes & 1,830 & - & 1,965 & - & - & - \\
\hline Total (valid) & 153,360 & - & 153,225 & - & - & - \\
\hline Total & 155,190 & - & 155,190 & - & - & - \\
\hline
\end{tabular}

${ }^{\mathrm{a}}$ The election of the Citizen Council uses a point system based on multiple vote.

bOther minor documents have been voted for at the II congress (for more details see: https://vistalegre2.podemos.info/resultados/).

faction. In sum, leadership dynamics have shown a growing level of internal fragmentation with uncertain consequences in the foreseeable future.

All in all, Podemos' experience presents both similarities and differences vis-à-vis the characteristics associated to the 'movement party' type. High levels of inclusiveness are facilitated by the low barriers to access party structures. But the intensity of participation varies substantially and the quality of deliberative processes seems quite low. Indeed, it has been noted that only 10 per cent of Plaza Podemos users are active, as shown by the number of comments, ${ }^{20}$ whereas argumentation is sometimes weak (very often interventions only express the direction of vote or encourage other people to participate, see Borge and Santamarina, 2015, 2016). Another problem is that it remains difficult to hold leaders and representative accountable (Interview 2). More importantly, online instruments of participation are often disconnected from the party's main bodies, and more effective bottom-up decision-making processes - such as citizens' initiatives, recall or extraordinary congresses - have never been implemented for lack of support. ${ }^{21}$

\section{Voters' support and mobilization strategy}

It is well known that new parties' strategic choices on organizational models and interparty competition have a crucial impact on their electoral support base (Bolleyer and Bytzek, 2017). To what extent does Podemos' electoral base converge with that of other populist parties? Can Podemos be considered a protest party or does it mobilize new voters? This section aims to address these questions by using survey data from the 2015 general elections.

During the early period, Podemos was the institutional face of social movements that defended a renewal of politics and new channels of participation. Therefore, the fight against corruption, anti-party sentiments, and political mistrust were at the heart of the first wave of mobilization that led to the emergence of this new party. Yet Podemos was able to increasingly politicize issues associated to the crisis. This shift had a marked effect on the profile of Podemos supporters, and also increased the potential to reach more discontented groups of voters.

The analysis made by Fernández-Albertos (2015) suggests that the Podemos electoral support base has changed significantly over its short life. In the 2014 European elections, Podemos voters were mainly young, with high levels of education and very involved in politics. But as Podemos expanded, it made considerable inroads into the groups most affected by the crisis, namely those with a negative perception of the economy and more frustrated by the lack of opportunities. Overall, the new party seems to register a shift in emphasis from post-materialist values to more materialist issues, and the increasing importance of economic voting.

\footnotetext{
${ }^{20}$ See the empirical analysis of participation patterns of Plaza Podemos in the Iagovar blog (http://iagovar.com/plazapodemos-como-ha-funcionado-hasta-ahora/).

${ }^{21}$ I would like to thank one of the referees for highlighting this important aspect.
} 
We now turn to the analysis of the determinants of Podemos voters in the 2015 general elections. We draw on the 2015 Centro de Investigaciones Sociológicas (CIS) post-electoral survey (Centro de Investigaciones Sociológicas, 2015) to test how political discontent and performance evaluation affect the probability of voting for the new radical left party. Political discontent is tested by including three variables in the model, namely: 'non voter', which aims to gauge the capacity to mobilize new voters, 'satisfaction with democracy' and 'trust in political parties'. The performance component includes two variables based on the evaluation of Spain's political and economic situation (at the national level), and whether the crisis led to the loss of employment. We also control for the main sociodemographic variables such as gender, age, education, religion, ideology, and partisan attachments (see Appendix A for the coding of variables). ${ }^{22}$ Given that our dependent variable is a nominal variable (the vote for the main Spanish parties), we use multinomial regression analysis (Dow and Endersby, 2004). ${ }^{23}$

Table 3 reports the determinants of Podemos' voters vis-à-vis the main parties. The model explains voters' behaviour in Spain quite well. The Pseudo-R2 indicates that more than twothirds of the variation in the dependent variable is explained. First, both political discontent and performance evaluation were important drivers for voters to choose the new radical left party. People who were more dissatisfied with democracy and the economic situation were more likely to vote for Podemos than for the two main governing parties. However, there was no distinction between the two radical parties in terms of protest and economic voting. Second, ideology again separates the two moderate parties from Podemos, but is not statistically significant in the case of IU.

The findings related to the impact of partisan attachments are also interesting. They suggest this is a powerful predictor of why voters preferred Podemos over both the socialists and also IU. As expected, 'new politics' was a hallmark of the new party's message, which aimed to challenge the (intra-party) functioning of traditional parties. Moreover, as many supporters experienced the grassroots mobilization of social movements during the crisis, Podemos' electoral support base did not identify with any of the parties representing the establishment. In addition, the impact of the 'non voter' clearly demonstrates mobilization capacity as it is statistically significant for the choice between PSOE and Podemos. Finally, there is a marked difference between mainstream actors and the new party in terms of education, with voters with higher levels of skills more likely to vote for Podemos. On the other hand, the new party was able to mobilize young voters; in particular, they chose to vote for Podemos rather than for mainstream parties or the more conventional radical left party (IU). Overall, the results thus confirm that the profile of Podemos is very close to that of the radical left party family, while the crisis and discontent with the government have led to a 'natural' convergence between this new party and IU. From this point of view, our findings seem to confirm those of Ramiro and Gómez (2017), who found significant impact related to the crisis. ${ }^{24}$ Although our data do not allow us to examine the impact of Podemos' electoral growth on the profile of its supporters, the results suggest a substantial differentiation between this new party and mainstream (left-wing) forces, contributing to the establishment of this actor as a permanent feature of the Spanish party system.

Podemos' breakthrough was possible due to its capacity to attract support both from people who were dissatisfied with the economic situation and from the electorate with strong anti-party feelings. On the one hand, retrospective accountability had a considerable impact on Podemos' performance. On the other, it was a vote against the 'caste' and the self-referential politics enacted by the 'cartel' between the PP and the PSOE. These general characteristics help explain Podemos' capacity to attract support from heterogeneous groups. We believe that these results provide a

\footnotetext{
${ }^{22}$ Unfortunately, the data do not enable us to test the impact of Eurosceptic attitudes, which previous studies found to be an important predictor of Podemos voters' support (Ramiro and Gómez, 2017).

${ }^{23}$ The reference category is the vote for Podemos.

${ }^{24}$ However, it should be noted that the data considered in previous studies were not based on the 2015 General elections.
} 
Table 3. Podemos' electoral support base (2015 elections)

\begin{tabular}{|c|c|c|c|c|c|c|}
\hline & \multicolumn{2}{|c|}{ PP } & \multicolumn{2}{|c|}{ PSOE } & \multicolumn{2}{|c|}{ IU } \\
\hline & $B$ & SE & $B$ & $S E$ & $B$ & $S E$ \\
\hline Constant & -8.89 & 1.15 & .35 & .92 & -.78 & 1.54 \\
\hline Gender & .01 & .20 & $.38^{\star \star}$ & .17 & $.52^{\star}$ & .28 \\
\hline Age & $.01^{\star}$ & .01 & $.02^{\star \star}$ & .01 & $.03^{\star \star}$ & .01 \\
\hline Education & $-.23^{\star *}$ & .10 & $-.42^{\star \star \star}$ & .09 & .19 & .14 \\
\hline Religion & $.32^{\star \star \star}$ & .10 & .13 & .09 & -.25 & .18 \\
\hline Working class & .28 & .31 & .35 & .25 & .47 & .40 \\
\hline Ideology & $1.99^{\star \star \star}$ & .09 & $.24^{\star \star \star}$ & .07 & -.09 & .11 \\
\hline Party identification & -.24 & .21 & $-.56^{\star \star \star}$ & .17 & $-.81^{\star \star \star}$ & .30 \\
\hline Nonvoter & -.21 & .40 & $-.62^{\star}$ & .32 & -.62 & .62 \\
\hline Satisfaction democracy & $.14^{\star \star \star}$ & .05 & $.11^{\star \star \star}$ & .04 & -.03 & .06 \\
\hline Trust in parties & .04 & .05 & .01 & .04 & -.10 & .07 \\
\hline Political situation & .14 & .14 & .15 & .12 & .11 & .20 \\
\hline Economic situation & $.56^{\star \star \star}$ & .15 & $.23^{\star}$ & .13 & .24 & .21 \\
\hline Lost job & $-.45^{\star \star \star}$ & .22 & -.16 & .18 & -.29 & .29 \\
\hline Observations & $(2657)$ & & & & & \\
\hline Pseudo $R^{2}$ & .66 & & & & & \\
\hline
\end{tabular}

Source: CIS post-electoral survey, 2015 general elections.

Note: Multinomial regression (reference category is the vote in Podemos).

${ }^{\star \star \star} p<0.001 ;{ }^{\star \star} p<0.05 ;{ }^{*} p<0.1$.

better understanding of why many voters dissatisfied with the incumbents opted to vote for this new party instead of relying on the main opposition forces.

The evidence from public opinion surveys tells us that Podemos' support stems mainly from a protest vote and its capacity to differentiate the supply side - compared to the traditional left - by appealing to less ideologically radicalized groups, dissatisfied with mainstream politics and those most hit by the crisis (people who lost their job are more likely to vote for Podemos rather than the incumbent party). We believe that one of the factors explaining Podemos' success - but also one of its weaknesses in the medium-long term - is its capacity to intercept anti-establishment protest voters, especially leftist groups that are more ideologically aligned with the core socioeconomic issues defended by this new party.

\section{Conclusions}

Our analysis of Podemos, a new party that brought innovations to Spanish politics and its party system, allows us to reexamine the debate about the 'novelty' of left-wing populist parties in Western Europe, especially in terms of party models and the interaction between party formation and party adaptation.

The analysis of the linkage between Podemos and citizens reveals several features that could characterize it as a 'post-modern' party. A first distinctive aspect of this party is its use of new ICT, which has fostered 'post-bureaucratic' organizations (Bimber, 2003) based on lightweight party structures. This has affected several aspects of this new actor, namely in terms of organization, ideology, and electoral support, each of which we discuss below. By exploring the potential of digital tools and social media to aggregate demands and 'empower' citizens, Podemos has breathed new life into the myth of deliberative and participatory democracy, and also strengthened local mobilization and the voters' belief in effective politics; it therefore contrasts with the growing trend of disenchantment with politics and increasing disaffection.

A second important innovation is the 'stratarchical' or 'franchise' type of organization (Carty, 2004; Bolleyer, 2008), which is also a feature of other populist parties such as the M5S (Bordignon and Ceccarini, 2013). While the party in central office defines the 'product' to be sold - 
leadership, ideology or strategy -, local units are relatively autonomous to mobilize their own resources and to choose local candidates and issues. This structure is particularly suited to multilevel politics, like that of Spain, with a functional differentiation between the centre and the periphery, and it brings several advantages for a newborn party. On one hand, it maximizes party flexibility, which makes it easier to neutralize the tensions inherent to its evolution and the uncertainties of the environment. On the other, it also boosts horizontal linkages and facilitates the mobilization of sympathizers and nonmembers, facilitating the connection with social movements. Moreover, little investment in organizational resources is required. Finally, the structure also helps neutralize internal conflicts and solve factional problems, like the ones that affected Podemos in its early stages. The fact that 'localist' proposals put forth in the last congress (Vistalegre II) by Errejón were rejected seems to suggest an increase in the power of the secretary-general and his coterie.

Despite these innovations, Podemos' organization is an odd mixture of direct democracy (especially at the local level) and a plebiscitary leadership. While the genetic model is clearly inspired by the loose structure adopted by movement parties, the importance placed on personalization and top-down links in intraparty democracy has increased as the party has evolved. As a result, Podemos seems to be positioned at the junction between different organizational models, leading to a sui generis party type. Several indicators also suggest that Podemos has entered a new stage, becoming increasingly similar to traditional parties characterized by internal quarrels, competition for leadership and growing professionalization. The evolution of Podemos shows that this new party clearly differs from the (organizational) model of populist parties, which relies on the role of charismatic leadership. Internal tensions and the 'normalization' process, that is, the institutionalization of party leadership and the establishment of more vertical links, led to a trend towards demobilization (see Appendix B). However, after two legislative elections it seems that the party has been able to stabilize internal mobilization to some extent, with approximately one-third of sympathizers participating in electoral processes. This trend was recently confirmed at the 2017 party meeting, where the 'cesarist' model auspicated by Iglesias clearly prevailed, granting more power and autonomy to the party leader. Yet the institutionalization of party factions may fuel internal conflicts and endanger the equilibrium in the power relation of party elites. The future of Podemos will also depends on party strategy, especially the position vis-à-vis the socialist government (in office since June 2018) and the potential cooperation - and competition - with the PSOE.

Moving to the ideological dimension, Podemos has certainly adopted a populist discourse that aims to divide the political space into two camps, opposing civil society to the 'corrupt elite'. However, Podemos has increasingly shown a catch-all appeal, not only by moderating its discourse, but also by depoliticizing some important dimensions. Our analysis of Podemos revealed depoliticization in at least two aspects. First, Podemos did not empower the labour movement and was unable to build a coherent and stable support base around clearly identifiable social sectors (Mateo, 2016). Second, the new party prompted a national-popular rhetoric that is quite atypical in the tradition of the Spanish Left, thus innovating the discourse framework used to communicate and mobilize its supporters (Briziarelli, 2016). Examining how and to what extent ideology impacts party types is an interesting avenue for future research, developing Gunther and Diamond's (2003) seminal contribution.

As for the electoral support base, we have shown that even within 'anti-austerity' parties there are important differences in terms of voter's profile. Although the distinction with the traditional left is clear-cut, Podemos differentiates also from IU, showing its capacity to match a new programmatic supply with the demand of citizens whose preferences were misrepresented within the old party system. The Podemos vote clearly incorporates a significant amount of dissatisfaction with the political system and the way the government has performed. Yet ideological and partisan identities (or lack thereof) are also important and this explains the strategic dilemma that the party has to face in the days to come. This is all the more important as 
Podemos' electoral breakthrough seems not to be associated to the emergence of a new (socioeconomic) cleavage.

After analyzing the different components of Podemos, this new party can be likened to radical left parties, but with two important innovations. On the one hand, it has adopted a technopolitical organization with the particularity of seriously addressing the digital revolution and its consequences for contemporary political parties and the functioning of representative democracies. In other words, Podemos can be understood as a version of the left-libertarian parties in the Web 2.0 era. On the other hand, Podemos shares a similar populist strategy with the M5S and SYRIZA, but it presents significant differences in terms of organizational model. Given the ongoing process of disintermediation and de-bureaucratization and the growing expansion of new digital devices, Podemos may well represent a new pattern of party development, characterized by the combination of assembly-based organizational style and a frequent use of plebiscitary decision-making practices (Poguntke et al., 2016). The main implication of this study is that the analysis of party types needs to take into account not only the genetic model, but also the electoral and societal environment. Both elements contribute to shaping the hybridity of party models and the instruments used to develop their functions. In addition, the multidimensional analysis of Podemos has shown that the interaction between the genetic model and the environment makes it difficult to frame (left-wing) populism within the party type literature. Such a (multidimensional) redefinition of new parties underlines the need to reformulate the concept of 'populist parties' in order to lessen some of the conceptual confusion in the literature and to enable new comparisons.

Acknowledgment. The author would like to thank the anonymous reviewers for their useful comments and constructive criticism.

Funding. The research has been funded by the Fundação para a Ciência e Tecnologia (FCT) through a grant within the framework of the project 'Crisis, Political Representation and Democratic Renewal: The Portuguese case in the Southern European context' (PTDC/IVC-CPO/3098/2014).

Data. The replication dataset is available at http://hedata.harvard.edu/dvn/dv/ipsr-risp

Author ORCID. (iD) Marco Lisi https://orcid.org/0000-0001-9833-0347

\section{References}

Backes U and Patrick M (2008) Communist and Post-Communist Parties in Europe. Göttingen: Vandehoeck \& Ruprecht. Barr RR (2009) Populists, outsiders and anti-establishment politics. Party Politics 15(1): 29-48.

Bimber B (2003) Information and American Democracy: Technology in the Evolution of Political Power. Cambridge and New York: Cambridge University Press.

Bolleyer N (2008) Inside the cartel party: party organisation in government and opposition. Political Studies 57(3): 559-579.

Bolleyer N and Bytzek E (2017) New party performance after breakthrough: party origin, building and leadership. Party Politics 23(6): 772-782.

Borge Bravo R and Eduardo Santamarina S (2015) "From the streets into institutionalization: online deliberative practices in new parties in Catalonia and Spain." Paper presented art the International Conference: Protest Participation in Variable Communication Ecologies, Università degli studi di Sassari, June 24-26.

Borge Bravo R and Eduardo Santamarina S (2016) From protest to political parties: online deliberation in new parties in Spain. Media Studies 7(14): 104-122.

Bordignon F and Ceccarini L (2013) Five stars and a cricket. Beppe Grillo shakes Italian politics. South European Society and Politics 18(4): 427-449.

Briziarelli M (2016) To 'feel' and to 'understand' political struggle: the national-popular rhetoric of Podemos. Journal of Communication Inquiry 40(3): 287-304.

Calise M (2015) The personal party: an analytical framework. Italian Political Science Review/Rivista Italiana di Scienza Politica 45(3): 301-315.

Calossi E (2016) Anti-Austerity Left Parties in the European Union. Competition, Coordination, Integration. Pisa: Pisa University Press.

Carty RK (2004) Parties as franchise systems. Party Politics 10(1): 5-24. 
Casero-Ripollés A, Feenstra RA and Tormey S (2016) Old and new media logics in an electoral campaign: the case of Podemos and the two-way street mediatization of politics. The International Journal of Press/Politics 21(3): 378-397.

Centro de Investigaciones Sociologícas (2015) Post-electoral survey. 2015 General Elections (study 3126). Madrid: CIS.

Chiocchetti P (2017) The Radical Left Party Family in Western Europe, 1989-2015. New York: Routledge.

Crouch C (2004) Post-Democracy. London: Polity.

Damiani M (2016) La Sinistra Radicale in Europa. Italia, Spagna, Francia E Germania. Roma: Donzelli.

Dow JK, and Endersby JW (2004) Multinomial probit and multinomial logit: a comparison of choice models for voting research. Electoral Studies 23(1): 107-122.

Duverger M (1981) Les Partis Politiques. Paris: Armand Colin.

Errejón I and Mouffe C (2016) Construir Pueblo. Madrid: Içaria.

Fernández-albertos J (2015) Los votantes de Podemos. Madrid: Catarata.

García de Blas E (2017) Las claves del congreso de vistalegre 2. El Pais, 10 February 2017. Retrieved 20 May 2018 from https://elpais.com/politica/2017/02/10/actualidad/1486714637_185757.html

García Agustín Ó and Briziarelli M eds (2018) Podemos and the New Political Cycle. New York: Palgrave.

Gerbaudo P (2015) Podemos: Radical Blueprint for Democratic Reform. Retrieved 18 December 2015 from https://www. opendemocracy.net/can-europe-make-it/paolo-gerbaudo/podemos-radical-blueprint-for-democratic-reform

Gomez R and Ramiro L (2017) The limits of organizational innovation and multi-speed membership: Podemos and its new forms of party membership. Party Politics, https://doi.org/ 10.1177/1354068817742844.

Gómez R, Morales L and Ramiro L (2016) Varieties of radicalism: examining the diversity of radical left parties and voters in Western Europe. West European Politics 39(2): 351-379.

Gómez-Reino Cachafeiro M and Plaza-Colodro C (2018) Populist Euroscepticism in Iberian party systems. Politcs 38(3): 344-360.

Guedán Vidal M (2016) Podemos: Una historia colectiva, Madrid: Ediciones Akal.

Gunther R and Diamond L (2003) Species of political parties. Party Politics 9(2): 167-199.

Heidar K and Saglie J (2003) Predistined parties? Party Politics 9(2): 219-239.

Hopkin J and Paolucci C (1999) The business firm model of party organization: Cases from Spain and Italy. European Journal of Political Research 35(3): 307-339.

Iglesias P (2015) Understanding Podemos. New Left Review 93: (May-June) 7-22.

Katz RS and Mair P (1995) Changing models of party organization and party democracy: the emergence of the cartel party. Party Politics 1(1): 5-28.

Katz RS and Mair P (2009) The cartel party thesis: a restatement. Perspectives on Politics 7(4): 753-766.

Keith D and March L (2016) Conclusion. The European radical left: past, present, no future?, in L. March and D. Keith eds. Europe's Radical Left. From Marginality to Mainstream?. London and New York: Rowman \& Littlefield, pp. 353-379.

Kioupkiolis A (2016) Podemos: The Ambiguous Promises of Left-Wing Populism in Contemporary Spain”, Journal of Political Ideologies 21(2): 99-120.

Kirchheimer O (1966) The Transformation of the Western European Party Systems, in J La Palombara and M Weiner (eds.). Political Parties and Political Development. Princeton: Princeton University Press, pp. 177-200.

Kitschelt H (1988) Organization and strategy of Belgian and West German ecology parties: a new dynamic of party politics in Western Europe? Comparative Politics 20(2): 127-154.

Kitschelt H (2006) Movement parties, in Richard S. Katz and William J. Crotty (eds). Handbook of Party Politics. London: Sage, pp., 278-290.

Koole RA (1994) The Vulnerability of the Modern Cadre Party in the Netherlands, in RS Katz and P Mair (eds.). How Parties Organize. London: Sage, pp. 280-301.

Kriesi H-P (2014) The populist challenge. West European Politics 37(2): 361-378.

Kriesi H-P, and Pappas TS (eds) (2015) European Populism in the Shadow of the Great Recession. Colchester: ECPR Press.

Krouwel A (2006) Party models, in R. S. Katz and William J Crotty (eds). Handbook of Party Politics. London: Sage, pp. 249-269.

Krouwel A (2012) Party Transformations in European Democracies. New York: SUNY press.

Mair P (2011) Bini Smaghi vs. the parties: representative government and institutional constraints. EUI working papers, RSCAS 2011/22, Robert Schuman Centre for Advanced Studies, EUI: Florence.

March L (2011) Radical Left Parties in Europe. Abingdon: Routledge.

Mateo JP (2016) The new left in Spain: some aspects to consider. Capital \& Class 40(1): 168-175.

Martín I (2015) Podemos Y Otros Modelos de Partido-Movimiento. Revista Española de Sociología 24, $107-114$.

Martos Garcia A (2015) Podemos: Crónica de un renacimiento. Madrid: Createspace.

Mcdonnell D (2016) Populist leaders and Coterie charisma. Political Studies 64(3): 719-733. doi: 10.1111/1467-9248.12195.

Mudde C (2007) The Populist Right Parties in Europe. Cambridge: CUP.

Mudde C and Kaltwasser CR (2013) Exclusionary vs inclusionary populism: comparing contmeporary Europe and Latin America. Government and Opposition 48(2): 147-174.

Müller JF (2014) \#Podemos. Desconstruyendo a Pablo Iglesias. Madrid: Deusto. 
Neumann S (1956) Modern Political Parties - Approaches to Comparative Politics. Chicago: Chicago University Press.

Oesch D (2008) Explaining workers' support for right-wing populist parties in Western Europe: evidence from Austria, Belgium, France, Norway and Switzerland. International Political Science Review 29(3): 349-373.

Panebianco A (1988) Political Parties: Organization and Power. Oxford: Oxford University Press.

Pauwels T (2014) Populism in Western Europe: Comparing Belgium, Germany and the Netherlands. Abingdon: Routledge.

Podemos (2014) Principios Organizativos. Madrid: Podemos.

Podemos (2015a) Estatutos del partido politico Podemos. Madrid: Podemos.

Podemos (2015b) Queremos, Sabemos, Podemos. Um programa para cambiar nuestro país. Madrid: Podemos.

Podemos (2016) Podemos. Programa electoral elecciones generales 26J. Madrid: Podemos.

Poguntke T, Susan ES and Paul Webb P (2016) Party rules, party resources and the politics of parliamentary democracies: how parties organize in the 21st century", Party Politics 22(6): 661-678.

Politikon (2015) Podemos: la cuadratura del círculo. Madrid: Debate.

de Prat CRA (2015) Semejanzas Y Diferencias Entre El Movimento 5 Stelle Y Podemos. Societàmutamentopolitica 6(11): 51-74.

Ramiro L (2016) Riders on the Storm: United Left and Podemos during the 2008 Great Recession, in L. March and D. Keith (eds.), Europe's Radical Left: From Marginality to the Mainstream? London and New York: Rowman \& Littlefield, pp. 311-330.

Ramiro L and Gómez R (2017) Radical-left populism during the Great Recession: Podemos and its competition with the established radical left. Political Studies 65(1S): 108-126. doi: 10.1177/0032321716647400.

Rivero J (2015) Podemos. Objetivo: asaltar los cielos. Madrid: Planeta.

Rodríguez-Teruel J, Barrio A and Barberà $\mathbf{O}$ (2016) Fast and furious: Podemos' quest for power in multi-level Spain. South European Society \& Politics 21(4): 561-585. doi: 10.1080/13608746.2016.1250397.

Rooduijn M (2014) The nucleus of populism: in search of the lowest common denominator. Government and Opposition 49 (4): 573-599.

Rooduijn M and Pauwels T (2011) Measuring populism: comparing two methods of content analysis. West European Politics 34(6): 1272-1283.

Simón PC (2016) The challenges of the new Spanish multipartism: government formation failure and the 2016 general election. South European Society and Politics 21(4): 493-517. doi: 10.1080/13608746.2016.1268292.

Stanley B (2008) The thin ideology of populism. Journal of Political Ideologies 13(1): 95-110.

Tamames R (2016) Podemos? Madrid: Kailas editorial.

Tímermans A (2014) Podemos? Madrid: Última Línea.

Torreblanca I (2015) Asaltar los cielos. Madrid: Debate.

Tsakatika M and Lisi M (2013) Zippin' up my boots, goin' back to my roots': radical left parties in Southern Europe. South European Society \& Politics 18(1): 1-19.

Vèrge T (2007) Partidos Y Representación Politica: Las Dimensiones Del Cambio En Los Partidos Politicos Españoles, 1976-2006. Madrid: CIS.

Zaslove A (2008) Here to stay? Populism as a new party type. European Review 16(3): 319-336.

Cite this article: Lisi M (2019). Party innovation, hybridisation and the crisis: the case of Podemos. Italian Political Science Review/Rivista Italiana di Scienza Politica 49, 245-262. https://doi.org/10.1017/ipo.2018.20 